\title{
EXPLOSION HAZARDS IN ANAESTHESIA
}

\section{J M. Wishart, M.D * *}

ON REVIEWING THE LITERATURE on this subject, one is impressed with the relative scarcity of deaths due to this catastrophe in anaesthesia. Di. G. J. Thomas (1) reports that deaths due to file and explosions in the operating room occur in approximately one in 80,000 to 100,000 anaesthetic administrations. It is probable that fires or explosions, of either major or minor proportion, occur approximately five times in 100,000 cases Thus we see that the rates of mortality and morbidity due to explosions are low in comparison to the over-all rates in anaesthesia However, because of the prominence such ac̈cidents are given in the lay press, and the rather unkind attitude of the courts, we must always keep them very much in mind and take every precaution to prevent further occurrences. In my own practice I have exceeded the above statistics as I have been associated with three fires or explosions Fortunately none has been very serious or fatal.

In the past, precautionary suggestions to the hospitals and anaesthetists have been very much at variance: more humidrty or less, use of conductive flooring or not, use of conductive footwear or not, use of conductive rubber tubing and connections or not. It is probable that much of this confusion has been brought about by lack of uniform standards in the manufacture of these products and therefore difficulty of interpretation of the results In recent months some unitormity among manufacturers has been achieved and it is probable that more realistic recommendations will soon be forthcoming. Whenever safety measures are under discussion the standard reference authority is the National Fire Protective Association pamphlet, Recommended Safe Practices (6)

There are three factors necessary to permit a fire or explosion: (1) a combustible gas or vapour, (2) oxygen, (3) a source of ignition. It is evident that in almost every anaesthetic, with the exception of nitrous oxide, trilene combination, the first two factors are always present. We must realize that ether is just as flammable as cyclopropane, and that nitrous oxide in a mixture will not decrease the explosion hazard. In fact nitrous oxide will support a fire or explosion as it is broken down to nitrogen and oxygen

It has been suggested that the use of flammable agents should be stopped, and in fact in some hospitals in the United States there is a ban on cyclopropane This would apply a rather hazardous limitation on our practice, as many of our techniques depend on the use of one or more flammable agents. We feel very strongly, however, that such a regulation could apply when cautery, X-ray, etc, are to be used. John Bullough (2) in the Lancet suggests the use of " $T$ " connections and a hose to draw off flammable agents to prevent dangerous accumulations of such gases or vapours in the operating room I do not feel that this method

'Presented at a joint meetıng of the Ontano Division, Canadian Anaesthetists' Society and the Sections of Anaesthesia and General Practice of the Ontario Medica! Association at Kingston, Ontario, October 20, 1956.

* Peterborough, Ontario. 
would appeal to many of the anaesthetists in this country. Therefore it is to the source of ignition that we must turn to reduce this hazard. It is probable that with adequate care and cducation, all such sources of igrition could be eliminated or controlled to such an extent as to prevent any future fires or explosions Thomas (1), Orr (3), Jackson (4), and Dillon (5), in recent articles, are $\mathrm{m}$ essential agreement as to the means of controlling or limiting all sources of ignition. The human factor is the hardest to control

All electrical connections should be of explosion-proof type or situated at least five feet from the floor with no extension cord connections where concentrations of gas may ignite. Cautery should not be used without the specific consent of the anaesthetist and then not within two feet of the patient's mouth or of the gas machine if a flammable mixture is being used. X-ray equipment must be used with extreme caution as even the latest models produce open sparks. Open flame, smoking, etc , must be absolutely prohıbited near any anaesthetic location

Static electricity is the cause of most explosions on record and is also the most difficult to control. To this end wool, silk, nylon, etc, are banned in the operating and recovery rooms, relative humidity should be between 50 and 60 per cent; and there should be a constant crrculation of the air in the operating rooms Air conditioning is helpful though not essential. There are some who argue against its use on the grounds of increased static due to removali of carbon particles from the air.

The floors in the operating and recovery rooms should be of conductive type in order to equalize charges between equipment and personnel in the rooms Terrazzo flooring with closely spaced brass grids or one of the newer conductive composition floors 'are probably best All equipment--tables, charrs, machines, etc.-should be grounded to the floor by long open-link brass or bronze chans The longer the chains, the more contact with the floor and therefore the better the grounding. They can be fastened diagonally under the tables and stools to be out of the way They must also be regularly cleaned of dirt and wax with brush and detergent to maintain their conductivity.

Conductive rubber should be used throughout the operating room on mattresses, pillows, tubıng, bags, masks, etc, and on the anaesthetic machine. It is important to ensure that there is no insulating material, such as plastic connectors, to permit charges to develop Conductıve footwear helps to maintain an equality of potential between the personnel in the room Moistened leather soles do a similar service There are apparently some objections to conductive shoes because, it is stated, coatings of wax and dirt are non-conductive and render them useless Regular cleaning would overcome this objection if it were valid.

It is important to make sure that the anaesthetic machme is well grounded to the floor by the use of chans and conductive wheels. It was previously recommended that the Horton Intercoupler be used as an extra safeguard. This device was to reduce to a minimum the danger of static spark in the area where it was most serious by equalizing the electrical potential between the patient, operating table, anaesthetic machine, and the anaesthetist It is no longer recommended as broken wires in it are not readily noticed and thus a false sense of security often prevals Further, the use of conductive rubber and grounding of equipment 
renders its use unnecessary. One should be very careful, when working with a flammable mixture, in breaking the connections between the machine ard the patient or in moving either patient or machine. The use of the flush va ve or ıapid flow of any gas is also hazardous as the friction may produce enough static to ignite the gases in the machine

It is reported that the low voltage of endoscopic equipment precludes the possibility of explosion. I know of two incidents which would disprove this suggestion. Grease or oil should never be used to lubricate fittings around a gas machine or cylinder, as the pressure of the enclosed gases would cause it to explode or burn Regulators should never be used if there is any doubt as to the state of therr reparr. Dust should be removed from the cylinder valve opening betore it is connected to the regulator by partly opening the valve for a moment.

My own experience, as mentioned above, aas included three fires or explosions. One was a fire in a faulty ether machine use for tonsillectomies. Regular inspection by a qualified electrician would have prevented it The second was an explosion during an ether anaesthetic when a laryngoscope bulb shorted in some way during intubation No serious damage resulted, though the patient's throat was cut by the small pieces of glass The thrd was the most serious. On opening a large cylinder of oxygen, there was an explosion which caused mild first degree burns on the side of the patent's face, and second degree burns to my arm. The regulator on the oxygen cylinder disappeared in a spray of molten metal on the walls of the room and the regulator on the nitrous oxide cylinder was burned beyond use Investigations by insurance underwriters and the Fire Marshall's Department revealed no cause In a discussion with men trom the Ohio Company it was suggested that dust could collect in the older regulators and, under proper conditions, this could explode, as a result of spontaneous combustion. The newer regulators have filter screens which prevent this accumulation of dust.

\section{SUMMARY}

I have presented a résumé of the explosion hazards and some suggestions on how to circumvent this danger 1 have also presented a brief report of three personal cases of fire or explosion It is suggested that most fires or explosions are the result of carelessness or negligence on the part of operating room personnel Thus even when all safety measures, from the physical standpoint, are practised, it is necessary to ensure that all individuals present know of and practise all the satety precautions recommended

\section{RÉSUMÉ}

Sur 100,000 admmistrations d'anesthésie, il peut survenur envron cinq explosions ou cinq incendies, ce qur n'est pas considérable, mars cela devient très important si l'on considère less réactions dans les journaux et les mauvaises conséquences légales. Aujourd'hui, les mesures préventives de ces catastrophes sont mieux définies et plus uniformes qu'elles ne l'étaient autrefois is et, en conséquence, nous devrions pouvorr dıminuer leur pourcentage.

Pour produrre un feu ou une explosion, il faut réunir tıos facteurs: (1) un combustible gaz ou vapeur, (2) de l'oxygène, (3) une source d'ignition. A part 
le protoxıde d'azote et le mélange protoxide et trilène, tous les mélanges gazeux sont également inflammables et 1 faudrait éviter de les employer là où il existe un danger d'explosion.

La melleure façon d'aborder ce problème est par le contrôle de la source d'ignition. Les connections électriques doivent être à l'épreuve des étincelles ou situées à conq pieds du sol. En toute éventualıté, l'usage du thermocautère devrait ètre soumıs à l'approbation de l'anesthésiste. Les vêtements de nylon, de laine ou de sore devraient être exclus des salles d'opération et des salles de réveil. On recommande de maintenır dans les salles une crrculation d'arr constante et un taux d'humıdité varıant de 50 à 60 pour cent.

Les planchers des salles d'opération dorvent être conducteurs soit au moyen de fils métalliques conducteurs, sort en les recouvrant d'une composition conductrice. L'équipement complet de la salle d'opération dòt être pourvu d'une mise à terre au moyen d'une chaîne à malles ouvertes en survre, chaîne qu'il faut nettoyer réguhèrement avec une brosse et du détergent. Les membres du personnel doıvent porter des chaussures conductrices de façon à égalıser le potentiel électrique entre eux-mêmes et l'équipment. Tous les joints, les tuyaux de caoutchouc, les masques, les matelas, les oreillers, les courroies, etc., doivent être de caoutchouc conducteur de façon à prévenir les différences de potentiel en électricité statique. Les connecteurs en plastıque ou les champs en coton ne devraient pas être tolérés car ils interrompent la conduction.

On suggérait, autrefors, le "metteur en communication" de Horton dans le but d'égalıser le potentiel électrıque entre l'anesthésıste, le malade, la table et la machine, aujourd'hur, on a discontinué de l'employer à cause de la possibilité de l'existence ignorée de fils brisés Toutes les sources de friction-tel un courant rapide de gaz, une disconnection rapide sur une machine à anesthésie, etc.doivent être évitées. Là où on emploie des instruments endoscopiques, il vaut mieux employer un mélange non inflammable car autrement un curcuit dans l'outllage pourrait causer une explosion

L'auteur a été témoin, au cours de ses années de pratıque, de trois explosions d'abord avec de l'électricité et une machıne à éther défectueuse, ensuite avec un curcuit sur un laryngoscope et enfin à cause d'un amas de poussière sur un vieux régulateur d'un gros cylindre d'oxygène. Sur les régulateurs plus récents, on a placé des filtres pour prévenır l'accumulation des poussières Heureusement, aucun de ces accidents n’a été mortel ou sérieux

\section{REFERENCES}

1 Thomas, Geonge J Fire and Explosion Hazards with Flammable Anaesthetic Agents and Their Control Kentucky State M. A. J , 1 (January 1956).

2 Bullougr, John Anaesthetic Explosions Prevention by Withdrawal Method Lancet, 17 (Apnl 1954)

3. OrR, Robert B The Explosion Hazard. Surg Chin North Amer, Lahey Clinic, pp 751-9 (1950)

4 Jackson, Arnol. S Editorial J Internat Coll Surgeons, 23(3) 398-401 (March 1955)

5 Dixlon, John B Fires and Explosions in Anaesthesia Radiology, 65 108-110 (July-Dec 1955).

6 Recommended Safe Practice for Hospital Operatıng Rooms Boston National Fire Protective Association (1952) 